\title{
Status of the Mockingbird in the Northern Great Plains
}

\author{
by Frank H. Brazier, Regina
}

\section{Introduction}

During the past few years I have been struck by the relatively frequent occurrences of the Mockingbird (Mimus polyglottos) in Regina and other parts of Saskatchewan, for I have always considered the bird to be a real Southerner. This led me to attempt to make a survey of the status of this species in Saskatchewan. When I began to dig I soon realized that I had to go beyond the confines of the province to get a more complete and meaningful picture. I cast my net wider, covering the Great Plains north of $40^{\circ} \mathrm{N}$. Lat., and I also paid some attention to the areas to the east and west of this region. To get my information I examined the published material in the libraries of the Saskatchewan Museum of Natural History and the University of Saskatchewan, Regina Campus; in addition I carried on a great deal of personal correspondence with many observers in the Prairie Provinces, Montana, North Dakota, and Minnesota. Much interesting and unpublished information came to light. I know that I did not uncover every single instance of a Mockingbird occurrence in the area, but I believe that I have enough records to create a reliable picture. Manitoba, South Dakota, and Minnesota, especially, are not completely represented. Saskatchewan records, however, are believed to be nearly 100 per cent. Singing birds are noted to indicate probable males.

\section{Northward Spread}

A northward expansion of the range of the Mockingbird has long been recognized. The limits of the western race ( $M$. p. leucopterus) as established by Ridgway (1907:321) were southwest United States (Texas) to the Pacific Coast, northwest to southeast Wyoming, thence southwesterly. to central California. The range of the eastern race, in the central area, included Missouri regularly, but Iowa irregularly, southern Wisconsin, southern Minnesota and Ontario sporadically. Recently the range was revised (see A.O.U. limit lines on map, Fig. 1) A.O.U. Checklist, 1957:422-423): to include much of southern Canada, and the spread of the species was noted (A.O.U. Checklist, 1957: 422-423: ". . . [it] has spread north in recent years; now found casually to. southwestern British Columbia, southern Alberta, southern Saskatchewan, southern Manitoba, southern Ontario, southern Quebec, and Nova Scotia." The range for the eastern nace (M. p. polyglottos) is given as: "Casual in Nomth Dakota (Kenmare, Mandan, Fargo), southern Manitoba (Brandon, Winnipeg, Hillside Beach) . ..." The western race is noted as "casual in southern Alberta (Didsbury) and southern Saskatchewan (Wilcax) ..."

\section{Details of Northward Spread}

I have accepted as factual the reports of occurrences I have gathered, and have plotted these on a map (Fig. 1). I have also presented these records in tabular form so that several different factors may be more readily considered. In order to appraise the present status with some degree of accuracy I compiled a chronological table, indicating the source of the records (Table 2) for the entire study area. This shows that the bird has been appearing north of its stated limits since 1860 with increasing frequency. As will be noted I did not get many records for Manitoba but Mr. R. W. Sutton, Director of The Manitoba Museum, writes under the date of January 16, 1962: "Mockingbirds are reported here almost every year, though as yet we have no breeding record." It will be seen from Table 2 that the reported occurrences in any one year get more and more irregular the farther northwest we go. I also compiled a "Location Directory" with years of occurrences noted so that any area can be readily studied. Thus, to trace the occurrences in any area, one simply looks up the places in the Location Directory (p.76) for the years, and then looks up those years in Table 2; it is a cross-index between the map and Table 2. 


\section{Status Generally}

The Mockingbird is not common anywhere at or north of its limits as described by the A.O.U. Check-list (1957), in fact it is decidedly uncommon, but it is less uncommon on the eastern side of the study area (eastern South Dakota and eastern Minnesota) where it could be considered a rare breeder; elsewhere in the study area it is rare, although increasingly less rare, and a rare and irregular breeder.

\section{Status in Saskatchewan and Alberta ALBERTA}

With only 13 or possibly 14 records since 1928, Mockingbirds are of casual occurrence in Alberta. There is one breeding record. These are probably all of the western race, $M$. $p$. leucopterus. The remarkable occurrences on the farm of Mrs. Mary H. Keyte, near Pollockville, Alta. (SW 34-24-12-w4), where a singing Mockingbird appeared six consecutive springs (1955-1960) are most interesting. It could very well be the same bird but this is not known. Wing (1956:138) reports that there is a tendency for adult Mockingbirds to survive up to nine years of age; this factor increases the chance for the Pollockville record to have been the same bird.

\section{SASKATCHEWAN}

In Saskatchewan the Mockingbird is a rare visitor, and a rarer breeder, but occurring with increasing frequency. In Table 2, I have mentioned a report given me by $R$. D. Symons (from memory) of an occurrence in either 1923 or 1924 , as it fits in well with the unfolding picture. The first sighting recorded was by Steve Mann at Skull Creek on May 2, 1927; another was recorded on May 31,1928 , at the same place by his friend, Laurence B. Potter, who collected it (a male, the province's first specimen) on June 4, 1928 (Potter, 1943b). Mrs. Alice Miller, of Oxbow (fide Mrs. Keith Paton, pers. corr.) writes about one singing there in 1928, in the spring, ske thinks. Patter (op. cit.) states: "Subsequently Mockingbirds nested at various points in Saskatchewan, also in Alberta. The last Saskatchowan record of which the writer is aware was 1937." Presumably the Alberta reference was to the 1928 Didsbury breeding, but the remainder of the statement cannot be reconciled with the information I have. There was an attempted breeding at Wilcox in 1934, and Holmes collected one at Dollard in 1935. The Saskatchewan Museum of Natural History files contain a note that Potter saw two Mockingbirds at Eastend and collected one, but no dates are given-these records also contain a note that T. C. Lusted of Truax reported four Mockingbird nests there, and another pair between Truax and Rouleau in 1935. Probably Potter was referring to the 1935 nesting, but I can find nothing for 1937. Commencing with the 1927 report, the Saskatchewan records are shown in Table 1.

\section{Problem of Races in Saskatchewan}

Of the localities shown on the map (Fig. 1) those south and southwesterly of a line connecting Beadle -Dilke-Regina-Oxbow (including these) arc on Grassland, while the others are in Aspen Grove, except Prince Albert which is in Boreal Forest.

The A.O.U. Check-list (1957:423) has designated Mockingbirds in Saskatchewan as belonging to the western race (M. p. leucopterus). The specimens talken were all from Eastend in the extreme southwest corner of the province, but no specimen was taken of the Wilcox birds, and Wilcox is far removed from the southwest corner; there is a gap of about 185 miles beitween Wilcox and Eastend. It appears that the A.O.U. Check-list Committee assumed on geographical probabilities that the birds in eastern Saskatchewan were also of the western race. A recent examination of the distribution of the Mockingbird in the area in question leads me to coriclude that Saskatchewan Mockingbirds probably originate from both the southeast and the southwest and that hence both eastern and western races occur in Saskatchewan. The evidence also suggests that more of our Mockingbirds are of the eastern race (M. p. polyglottos) Other Mockingbirds have been recorded and taken relatively near both Eastend and Wilcox, but I have found no records from within the gap between these points, or in other words, between the lines plotted on the map (Fig. 1). At this stage it is illuminating to consider its status in South Dakota, where the "gap" commences 


\section{Status in South Dakota}

J. S. Firdley (1949:43) makes the comment that: "It surprises most of us to learn that Mockingbirds nest in South Dakota, but the records go back to 1860 ..." The Black Hills area in wesiern South Dakota has the western race of Mockingbirds recorded by a specimen, taken in 1860 , and breeding records are referred to that race - four or five pairs at Smithwick in 1936 but no more until one secn in 1949; one or two pairs breeding at Ardmore 1935-1942 and $1945-1948$, seen at Hot Springs 19431949; seen east of Fairburn 1945. Findley reports more than a dozen instances of the eastern race occurring in the southeast quarter of the state but he does not know the race of the birds seen at Pierre in 1933 and 1936. They have been noted twice at Highmore, between Pierre and Huron, in 1960 and 1961 (South Dakota Bird Notes, 13:92) and two, one in breeding display, at Huron, April 30, 1961 (Sicuth Dakota Bird Notes $14: 23$, so the Pierre birds may represent a western thrust of eastern birds.

In the literature I have been able to examine I find evidence that Mockingbirds breed sparsely but fairly regularly in southeastern Scuth Dakota and these would appear to be east $€ \mathrm{rn}$ birds. There is a considerable gap with no recora's between the eastern birds and the western birds recorded in the vicinity of the Black Hills. The check-list of South Dakota Birds published in South Daketa Bird Notes (8:17) describes the Mockingbird as accidental in the northeast corner of the state, but a summer resident of the remainder, so the gap may well have a few Mockingbirds, perhaps breeding, in South Dakota; the Check-list remarks: "The bird life of many counties of the state is very poorly known." The A.O.U. Check-list recognizes that the two races intergrade in the eastern plains arca in Nebraska and Kansas, which is immediately adjacent to the south.

Some Conclusions Regarding Races

A search of Auduban Field Note: 3 to the end of 1961 turned up only one mention of Mockingbirds north of the A.O.U. limit, in 1956. The South Dakota sturly reveals a surprising similarity with the situation north of the A.O.U. limit; a gap seems to exist between the two races, and the gap continues northwestward, being widest between Grassrange, Montana, and Parshall, North Dakota. In Saskatchewan our western specimens were taken in the vicinity of the Cypress Hills in the southwest corner; unfortunately the condition of moult of the Regina specimen was too advanced for the bird to be classified by race. However, there have been a relatively large number of occurrences in the well-treed area to the east and a considerable number close by on the plains. If the line Struan - Elbow - Crestwynd - Truax - Parshall - Morristown - Pierre Platte (see Fig. 1) is considered as representing the western limit of the advance of eastern birds, and the line Beadle - Dollard - Grassrange - Fort Keogh - La Creek tha eastern limit of the advance of western birds, the gap I have mentioned becomes evident. This is all treeless prairie, except for brush in creek bottoms, and introduced shelter belts and ornamentals. It seems reasonable to believe that the more populous eastern race is moving up through the open forest country, northward along the prairie edge and thrusting out into the plains along watercourses where brush meets its requirements. Evidently scmething similar is occurring on the western side, the thrusts going northward along the well-treed foothills and eastward along watercourses. The pattern which shows up in South Dakota has progressed northwesterly, the gap being maintained all the way.

I have attempted to show that the distribution pattern of the two races of Mockingbirds as established in South Dakota, i.e., the western race in the southwest corner, a gap from which no Mockingbirds are recorded, and the eastern race in the southeast corner, persists northwesterly as far as Huxley, Alberta, and Struan, Saskatchewan. The gap is widest between Grassrange, Montana, and Parshall, North Dakota, and our evidence suggests that the spread of Mockingbirds is from the east westward of eastern birds, and from the west eastward of western birds. The birds attempting to breed at Wilcox, Saskatchewan, in 1934, were, in my opinion, most likely of the eastern race. The foregoing is, of course, guesswork based on geographical occurrences. We have no specimens (Continued on page 69) 
MOCKINGBIRD OCCURRENC

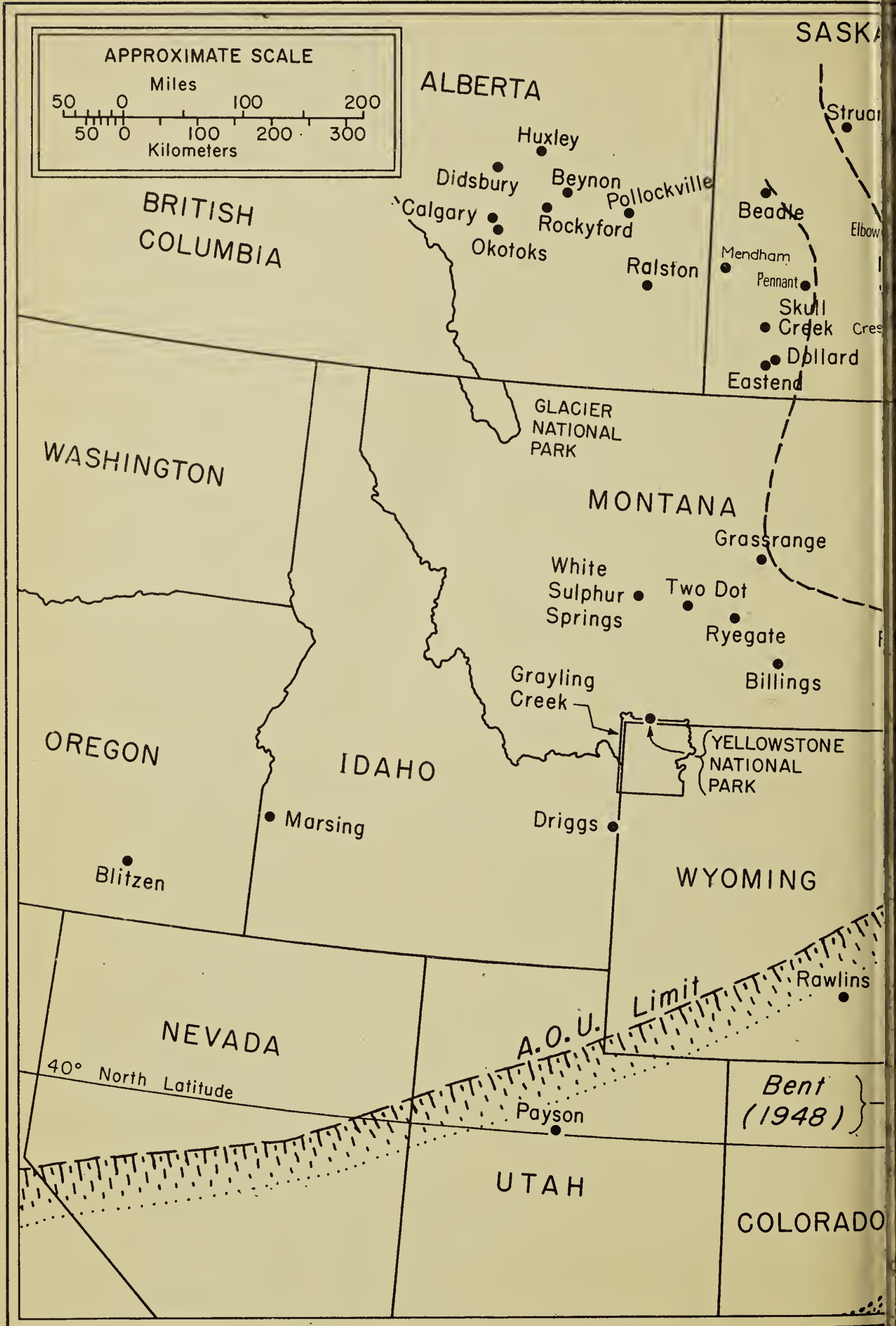




\section{NORTHERN GREAT PLAINS}

Ibert

an

en

ien, appelle

MANITOBA

ONTARIO

Lebret

Bina Grenfell

cox $\begin{gathered}\text { Oxbow } \\ \text { Kenmare }\end{gathered}$

Kenmare Refuge

- Parshall

NORTTH DAKOTA

- Wilton

Maldan $\bullet$ Bismarck

Winnipeg
Ste. Adolphe

Hillside

Delta Lac du Bonnet

(

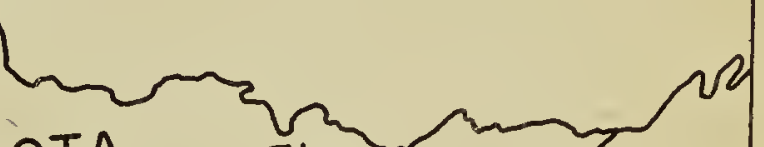

Belle

Fourche

1

1

Morristown

SOUTH

DAKQTA

Pierre Highmore Huron

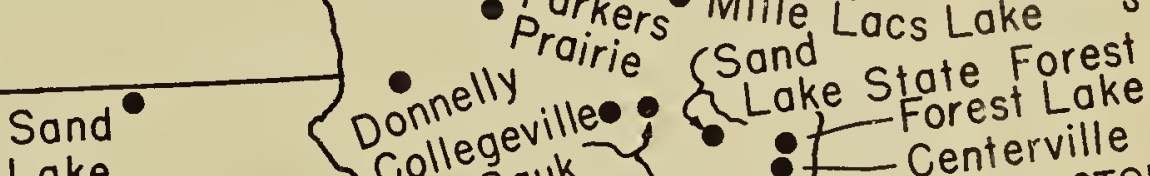

- Parkers Mille Lacs Lake

MINNESOTA

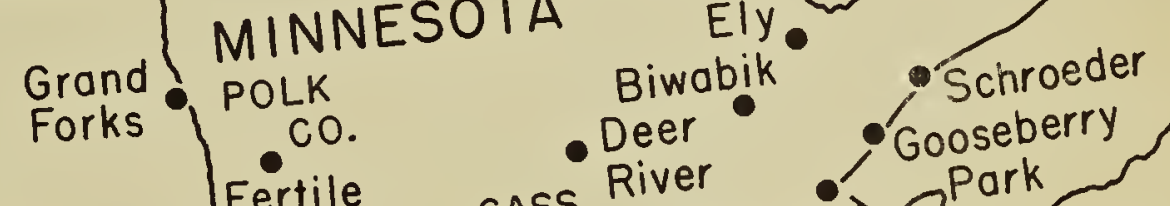

Fargo ${ }_{\text {Moorhead CO. AITKIN }}$

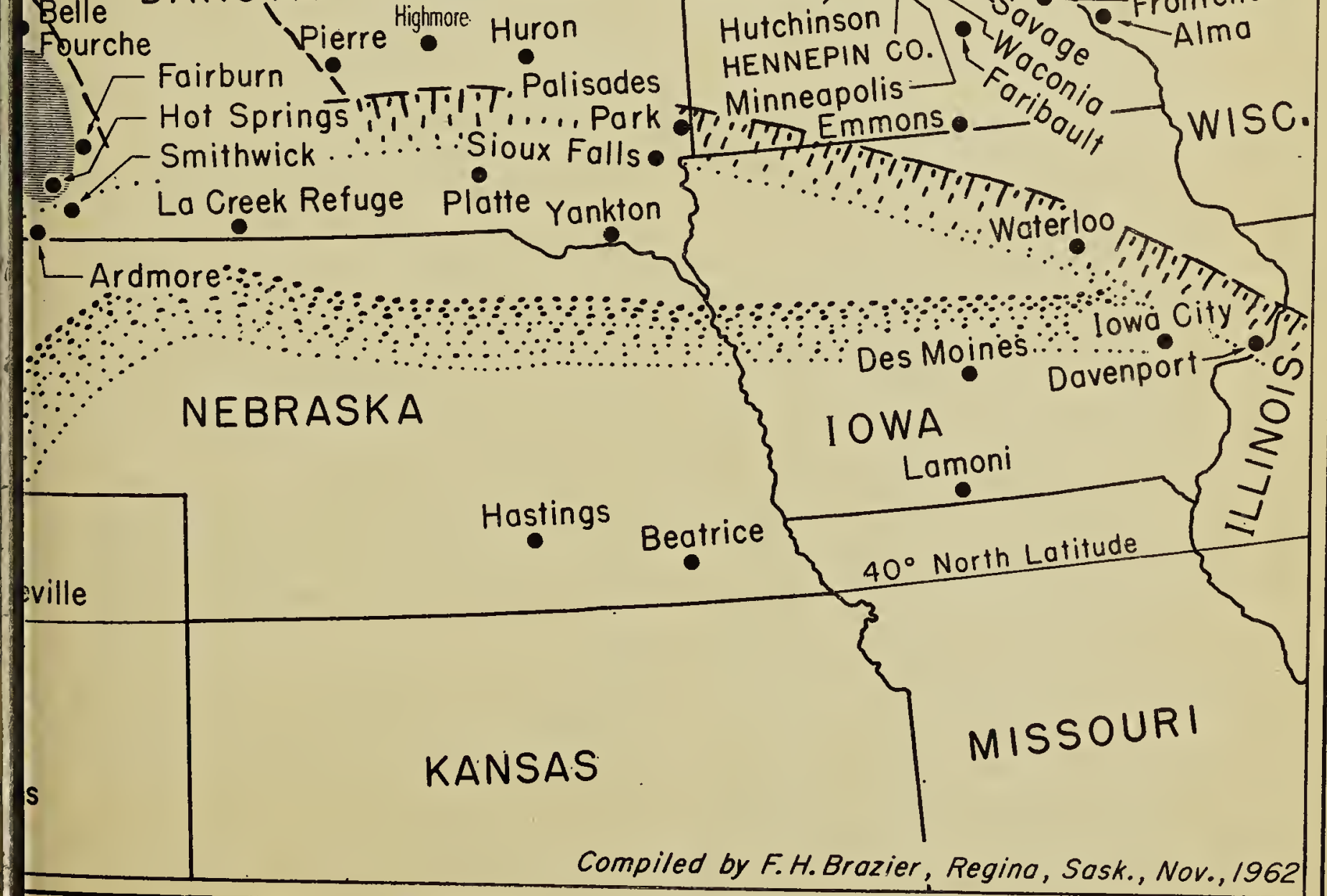

Compiled by F.H.Brazier, Regina, Sask., Nov., 1962 
Vol. XXII, No. 2

\section{Table 1-SASKATCHEWAN MOCKINGBIRD RECORDS, 1927-1963}

1927 May 2: 1 seen by Steve Mann at Skull Creek.

1928 May 31-June 4: 1 male collected by L. Potter at Skull Creek.

1928 ? spring: 1 singing 5 miles west of Oxbow, by Mrs. Alice Miller.

1929 Sept. 22: 1 seen at Oxbow by W. Languish.

1929 Nov. 1: 1 collected by. Steve Mann at Skull Creek.

1934 June 1-July 23: pair came to Wilcox and attempted to breed; female disappeared after nest constructed: male last seen July 23.

1934 Nov. 4: 1 seen at Regina by Jack Taylor.

1935 June 9: 1 collected at Dollard by C. F. Holmes.

1935 ? : 4 nests reported at Truax by T. C. Lusted, and 1 pair between Truax and Rouleau.

1935 Oct. 17: 1 seen at Regina by Jack Taylor.

1942 May 6: 1 seen in Regina by Dick Bird.

1946 July 6-July 16: 1 seen at Dollard by C. F. Holmes:

1953 June 5: 1 seen at Beadle by B. Gollop and D. Hurst.

1956 May 18: 1 seen at Struan by Mrs. F. A. Wilson.

1956 June 12-June 17: 1 seen at Regina by Elizabeth Cruickshank.

1957 May 31: 1 seen by R. V. Folker at Saskatuon.

1957 June 2: 1 seen at Dilke by Boswell Belcher and Margaret Belcher.

1957 Sept. 11: 1 found dead at Oxbow by Mrs. Keith Paton.

1957 Sept. 25: 1 heard singing in Regina by Fred Bard, Director of Saskatchewan Museum of Natural History.

1957 Oct. ?: 1 seen at Fort Qu'Appelle by Dr. J. G. Fyfe.

1958 May 14: 1 seen in Regina by Elmer Fox and Frank Brazier.

1958 May 25: 1 seen in Saskatoon by Dr. and Mrs. Gerrard.

1958 July 16: 1 seen $6 \mathrm{mi}$. west of Moose Jaw by Dr. G. F. Ledingham.

1958 July ?: 1 seen in Saskatoon.

1958 Oct.-Dec. 9: 1 seen in Saskatoon, finally killed by cat.

1959 May 4: 1 seen at Melville by Gary Anweiler.

1959 May 9-May 23: 3 seen in Regina by several observers.

1959 June 16: 1 seen in Regina by Elizabeth Barker.

1959 June 15-July 25: 1, possibly 2, seen in Oxbow off and on by Mrs. K. Paton.

1959 Aug. 30: 1 seen at Fort Qu'Appelle by Errol Cochrane.

1960 early June: 1 remained 9 weeks at Mendham, Sask.

1960 Oct.: 1 remained for some time at the home of Mrs. G. Headley in Saskatoon.

1960 Nov: 7: 1 seen at Grenfell by Mrs. John Hubbard.

1961 Sept. 26: 1 seen in Regina by Margaret Belcher.

1961 Oct. 9: 1 collected in Regina by Dr. R. W. Nero at same place as Sept. 26 bird.

1961 Nov. 21-Nov. 29: 1 seen at Lumsden by Tommy Mack.

1962 May 12: 1 seen at Regina by Elmer Fox.

1962 May 18: 1 seen at Fort Qu'Appelle by Manley Callin.

1962 May 25-June 6: 1 seen at Pennant by Earl J. Williams.

1962 June ?: 1 seen at Lumsden (photograph identified by Doug Gilroy).

1962 Oct. 5-Dec. 29: 1 remained in vicinity of home of Auguste Viala in

Prince Albert until last seen Dec. 29; found dead Jan. 2, 1963.

(Continent's farthest north record.)

1962 Dec. 3: 1 seen in Regina by Tom Shoyama.

1963 May 12: 1 seen at Regina by Ruth Tempel and others.

1963 May 18: 1 seen at Saskatoon by J. D. Hogg and J. Shadick.

1963 June 15: 1 seen at Crestwynd by Fred Bard and Fred Lahrman.

1963 June 26-July 5: 1 seen at Elbow by G. Keith Greene.

1963 July 13-July 15: 1 seen and heard at Lanigan by Bob Brenner, Don Eichorst, et al.

1963 Aug. 10: 1 seen at St. Louis by Auguste Viala. 


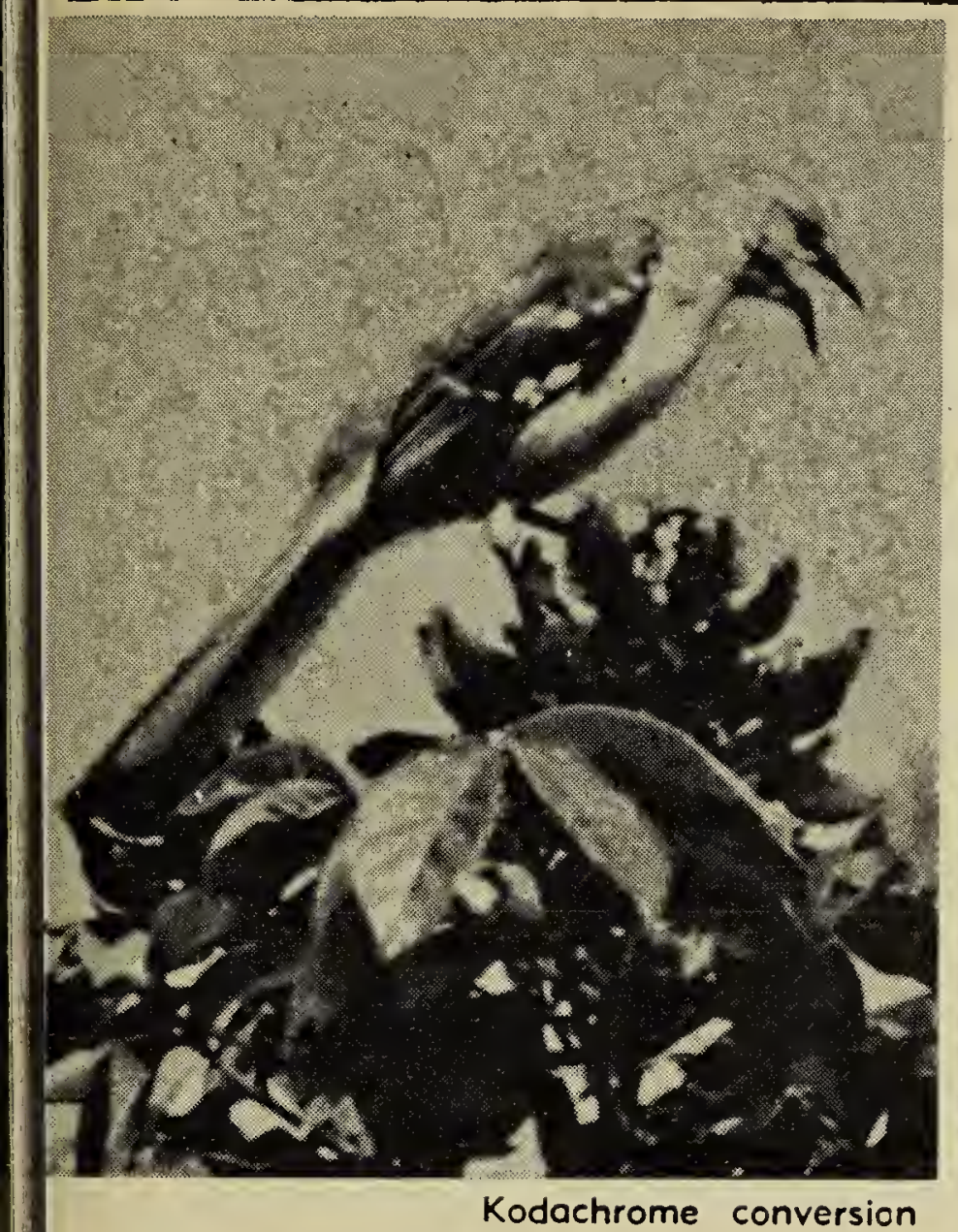

Mockingbird in Florida.

(Continued from page 65)

which have been classified as to race taken in the critical areas, i.e., east of the Struan-Mornistown line. Individual birds from the east may have occurred in the far west, and vice versa. It is also possible that there has been a movement of western birds northeastward, but if this is the case surely there would have been records from inside the gap. There is no doubt that specimens will be needed to provide a more definite picture.

\section{"Colonization" of Northern Areas}

The family Mimidae includes 30 species, the great majority of which reside in the tropics. The Mockingbird (Mimus polyglottos) is the northernmost of the nine species of mockingbirds found in the family. The greatest concentrations of populations of Mimus polyglottos are in the Gulf States and thus it may be considered a sub-tropical species. The evident spread northward could indicate population pressure in the most favourable habitat. Since 1948 there have been more than three times as many reports of Mockingbirds north of the limits as previously. This increase in reports probably means an increase in birds. This is supported by a rough index, the Christmas Bird

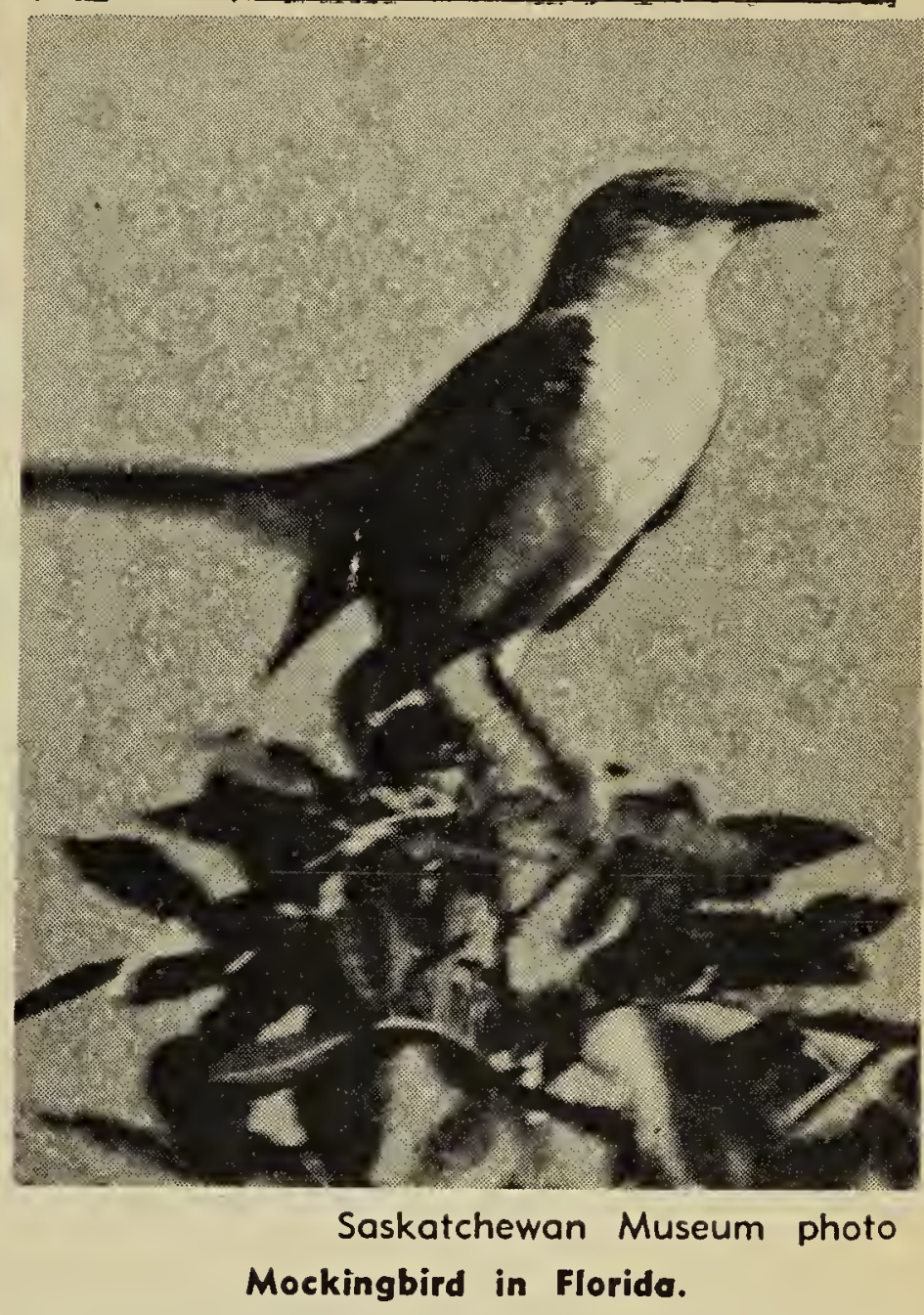

Counts as reported in Audubon Field Notes. Admittedly the variables over the period (differences in numbers of reporters and reporting points, etc.) rencier the Christmas counts inconclusive, but a population increase of some significance is indicated. Wing (1956:260) referring to the same censuses (with some reservations) includes the Mockingbird among the most abundant birds of eastern North America.

In spite of the number of reports I have gathered, I do not think we can say that the Mockingbird has successfully invaded the Northern Great Plains north of the A.O.U. limit. I believe we would have to have a reasonable succession of breeding reports from the same general area to consider the bird as established or successful. It is a tough and aggressive creature, two traits which spell success among bird species. It has prospered and is abundant at the centre of its range. Seeking a wider range by reason of its abundance, it appears to be pushing northward. This push northward, in time, might be successful. I believe that winter interrupts attempts of individual birds to establish territory; many of the reports are of single birds, singing, and then nothing. Nor do we have a single record, authenti- 
Vol. XXII, No. 2

cated beyond doubt, of a Mockingbird remaining throughout a winter and surviving into spring in the areas where the winters can get really savage as in Saskatchewan (although the one at St. Paul, Minnesota, 1952-1953 may qualify). But as a species it is persistent, as witness the many fall and winter records (see Table 2 ). These fall and winter occurrences, of such long-term and wide-range persistence, are really extraordinary. Suddenly in the fall a Mockingbird is seen when other birds are migrating south. Because of the vast area involved, and the abundance of brushy cover, this could indicate that a bird, a summer resident elsewhere, has been noted withdrawing to the south. It has been. established that birds of the year do, in the fall, spread out far from the natal nest, which might account for some of these records, although if this were the case one would expect far more breeding records. This spread of immatures in the fall probably is a means of preventing irbreeding and also a factor in enlarging the range. There are a significan $\hat{\imath}$ number of reports of a single bird seen in one place for a good period. This may indicate that the bird's response to territorial drive is so strong that it seeks a wintering home, well supplied with hanging fruit, to be on the spot in the spring. That this conjectured tactic is unsuccessful may well be traced to (a) failure of the food supply or death; (b) failure of a mate to apvear in the spring. We may be witnessing an initial period which will in time produce a successful extension of breeding range, as population pressure sends more birds out so that more mates appear. This tactic would be relatively more successful in the east where hanging fruit is more abundant than in the west-in both areas the bird would have to compete with established species such as the Bohemian Waxwing.

It is quite likely that the severity of the northern winters will hamper range extension, at least until the species learns to withdraw to the south. Being of southern origin the birds may not be equipped to overwinter; this is suggested by the fact that several have been found deadAuguste Villa found the Mockingbird which stopped at his home in Prince Albert beginning October 5, 1962, dead under its roost, apparently frozen to death. It was seen to feed well and there was no shortage of hanging fruit.

The theory that the Mockingbird seeks a territory in the fall and waits out the winter for a mate in the spring cannot be anything more than an hypothesis with the scanty information we have; there is only one record which provides a clue: the 1958-1959 Calgary winter record and the 1959 Beynon (Alberta) spring record. The records from Parshall, North Dakota (1958 autumn, 1961 breeding) would have been of this kind if a 1960 breeding in the vicinity went unnoticed.

The gap I have described may exist only because of incomplete records. Observers living in or near this area are urged to make further inquiries as to the past, and to watch for future occurrences so that its existence or otherwise may be established.

\section{TABLE 2-MOCKINGBIRD OCCURRENCES IN CHRONOLOGICAL ORDER FOR THE NORTHERN GREAT PLAINS AND ADJACENT REGIONS, SHOWING SOURCE OF RECORDS}

18601 (western race) taken in BLACK HILLS of South Dakota by Dr. F. Hayden.

$\begin{array}{llr}1860 & 1 \text { seen at PARKER'S PRAIRIE, Minn., June 1. } & \text { S.D. Bird Notes, } 1(3): 43 . \\ 1883 & \text { Roberts (1936). } \\ 1896 & 1 \text { seen at MINNEAPOLIS, Minn., June 11. } & \text { Roberts (1936). } \\ 1898 \text { A specimen from WACONIA, Minn., May 19. } & \text { Roberts (1936). } \\ 1916 \text { A specimen from GRAND FORKS, N.D., Nov. 23. } & \end{array}$

19171 seen at FRONTENAC, Minn., May 15. Wooc (1923). Considered accidental.
Roberts (1936).

1923 A pair at TUTCHINSON, Minn., May 24-June 24.

1923 R. D. Symons in 1961, stated from memory that he saw 1 singing on his ranch at or RENOWN, Sask.; he had heard of others that year, he thought, at LEBR.ET, Sask.. and 1924 CRAVEN, Sask. 
19271 seen by Steve Mann on his ranch ot SKULL CREEK, Sask., May 2.

Potter (1943a); Potter (1943b); Godfrey (1950).

1 seen singing $5 \mathrm{mi}$. west of OXBOW, Sask., in spring by Mrs. Alice Miller.

Roberts (1936).

1928 A pair nested at DIDSBURY, Albarta. Salt and Wilk (1958). Raised brood of 3.

Fide Mrs. K. Paton (pers. corrs.).

19281 seen at MINNEAPOLIS, Minn.. Nov. 5.

19281 found dead in WINNIPEG, Man., Dec. 21

1929

192.9

1930

1931

1932

1934

1934

1934

1935

1935

1935

1935

1938

1939

1939

1942

1942

1943

1943

1943

1946

1946

1946

1947

1948

19.49

1950

1950

1951

1951

1951

1952

1952

1952

1950

$-52$

1952

1953

1953

1953

1953

1953

1953

1953

1954

955

1 found dead in WINNIPEG, Man., in Dec.

I found dead in WINNIPEG, Man., in Dec. A pair nested at WILCOX, Sask., Júne 1 . T. C. Lusted.

1 seen at BEYNON, Alta., June 10.

1 taken at DELTA, Man., Sept. 17, immature.

1 seen at MOORHEAD, Minn., in May.

I seen at ROCK LAKE, N.D., May 31

1 seen at MOORHEAD, Minn., in July.

1 seen at DELTA, Man., Oct. 23,

1 seen at YANIKTON, S.D., Oct. 23.

1 seen at MORRISTOWN, S.D., in May.

1 seen at DEER RIVER, Minn., July 5. N. Randall.

(BLACK HILLS area.)

1 seen at FARGO, N.D., May 13.

1 seen at SAVAGE, Minn., May 31.

2 spent summer at CHEYENNE, Wyo.
Godfrey (1950:59). Roberts (1936).

Pers. corr. The Manitoba Museum.

1 seen at OXBOW, Sask., by Wm. Languish, on Sept. 22. Sask Mus. of Nat. Hist. record.

1 taken by Steve Mann at SKULL CREEK, Nov. 1. Godfrey (1950); Potter (1943).

Pers. corr. The Manitoba Museum.

Pers. corr. The Manitoba Museum.

1 at ELY, Minn., Dec. 26 to Feb. 11, 1933. The Flicker, March, 1937 (cited by R. Huber).

Boyd "About Birds." Female disappeared, male disappeared July 23. Breeding failure. (same report mentions I heard at SIASKATÓON, Sask.)

seen in REGINA Sask by Jack Toylor Nov Boyd "About Birds." No record exists. Belcher (1961).

1 singing at FORT KEOGH, Mont., on low sagebrush plain just west of Tongue River, May 14. The Condor, 38:175 (cited by Alan H. Brush). Seen by L. Ellison of Miles

City.

I taken at DOLLARD, Sask., by C. F. Holmes, June 9.

Godfrey (1950). Author notes that specimen has disappeared. 4 nests reported at TRUAX, Sask., and another pair between TRUAX AND ROULEAU by

I seen at REGINA, Sask., by Jack Taylor, Oct. 17. Sask. Mus. of Nat. Hist. record. Belcher (1961).

1 recorded during winter 1938-1939 at MINNEAPOLIS, Minn.

1 seen in REGINA, Sask., by Dick Bird, May 6.

The Flicker, March, 1947 (cited by R. Huber).

Audubón Mágazine Nio. 4, Sec. 2, p. 11 (cited by J. F. Cassell) 1948.

1 banded by Mrs. Gray at WILTON, N.D., June 3.

1 seen by H. B. Mills west of BILLINGS Mont., Sept. 5. Pers. corr. Prof. C. V. Davis.

1 male, singing at DOLLARD, Sask., by C. F. Holmes, July 6-16.

The Flıcker, June, 1952 (cited by 'R 4 (4):42. Pers corr. The Manitoba Museum.

Audubon Field Nates. considered unusual.

2 seen at MINOT, N.D., June 1 and 2, by Stanley Saugstad. Pers corr. J. Frank Cassell.

1 seen at FARIBAULT, Minn., Dec. 22. The Flicker. March, 1950 (cited by R. Huber).

The Flicker, June, 1952 (cited by R. Huber).

1 singing, at DICKINS (2 mi. west of WINNIPEG, Man.), June 9 and some days thereafter. Pers. corr. The Manitoba Museum-no nest, no other bird found.

1 seen in POLK COUNTY, Minn, July 1. The Flicker, June, 1952 (cited by R. Huber).

1 seen at MADISON, Minn., Nov. 18. The Flicker, June, 1952 (cited by R. Huber).

I seen south of MANDAN, N.D., May 25; 1 seen at BISMARCK, June 8, both by R.

Pers. corr. R. N. Randall.

1 seen near KENMARE, N. Dak, June 17-20, and either it or another seen at DES LACS REFUGE headquarters, June 23. Pers. corr. Mrs. R. T. Gammell.

1 seen in AITKIN COUNITY, Minn. Oct. 4. The Flicker. March, 1953 (cited by R. Huber). Several recorded from BELLE FOURCE, South Dakota

I seen at ST. PAUL, Minn., Dec. 1, 1952, to May 2, 1953.

S.D. Bird Nates.

1 seen at BEADLE, Sask., by G. Gollop and D. Hurst June 5.

4 seen at BILLINGS, Mont., June 10, by Mrs. Della Burchett.

The Flicker, Sept 1953 (cited by R Huber).

1 seen at EMMONS, Minn.. June 21 , by W. R. Pieper. The Flicker (cited by R. Huber).

1 seen at MINNEAPOLIS. Minn., in July. The Flicker, Sept., 1953 (cited by R. Huber).

1 seien at COLLEGEVILLE, Minn., Dec. 1, 1953, to Jan. $17 / 63$ specimen.

The Flicker, March, 1954 (cited by R. Huber).

2 singers seen in May on ranch near BILLINGS, Mont., again by Mrs. Della Burchett.

Pers corr. Mrs. D. Burchett and Prof. C. V. Davis.

1 singer at POLLOCKVILIE, Alta., May 28, by Mrs. Mary H. Keyte.

Pers. corr. Mrs. Mary H. Keyte.

2 singers seen in May on ranch near BILLINGS, Mont.. again by Mrs. Della: Burchett.

Pers. corr. Mrs. D. Burchett and Prof. C. V. Davis.

1 seen at TWO HARBORS, Minn., June 24. The Flicker, Sept., 1955 (cited by R. Huber).

3 seen at PLATTE, S.D., July 10. remaining all summer.

S.D. Bird Notes, 7:48 (by C. A. Nash). Audubon Field Notes, Aug., 1956. 
1955. I seen at DES, LACS REFUGE, N.D., Oct. 4-7.

Pers. corr Mrs. R. T. Gammell.

19551 seen in HENNEPIN COUNTY, Minn., Dec. 17, 1 in RAMSAY CO., Dec. 20.

1955 Wide distribution of Mocking Flicker. March, 1956 (cited by R. Huber). Dev 12 PLAT their norinal range noted: CHEYENNE, Wyo. Dev. 12, PLATTEVILLE, Colo., Nov. 26, LOVELAND, Colo.. 'Dec. 24, near DENVER; Colo., Dec. 26, at COLORADO SPRINGS, Colo., Dec. 26, I seen throughout December at HASTINGS, Nebr.

1956 I seenl at SAND LAKE REFUGE, COLUMBIA, So. Dak. Apr. 28.

19561 seen at PALISADE PARK, S.D., May 8.

1956

1956

1956

1956

1956

1956

1956

1956

1956

1956

1956

1957

1957

1957

1957

1957

1957

1957

1957

1957

1957

1958

19.5

1958

1958

1958

1958

1958

1958

1958

1958

1958

1959

1959

1959

1959

1959

1959

1959

1959

1959

1959

1959

1959 1 at SCHROEDER, Minn, MaY 22. singing.

1 seen at MILLBANK, S.D., Nov. 15. singing. remaining until killed by cat, Dec. 9. Record.)

3 seen in REGINA. Sask. May 9-May 23.

1 seen at BEYNON, Alta:, by Myrtle Biggs.
1955 I seen 5 mi. S.e. of KENMARE, N.D., May 1.8. P. Pers. corr. Mrs. R. T. Gammell.
1956 i singer at STRUAN, Sask. May 20th, by Mrs. F. A. Wilson. Bilue Jay. 14 (3): back cover. The Flicker, Sept., 1956 (cited by R. Huber). Others (no ?) at DRIGGS. Idaho, May 26, RAWLINS. Wyo., May 30. 1 at farm of Mrs. Keyte near POLLOGKVILLE, Alta, May 30, remainied for 'i week, 1 at FERTILE, Minn., June 10.
1 , singing, at REGINA, Sask.. seen by Mrs. Elizabeth Cruickshank, Junel 12, 13, 15, 17.

Pers. corr. Mrs. Mary H. Keyte. 4 seen July 10 at MINNEAPOLIS, Minn., by R. Huber. Blue Jay, 14 (3): back cover.

1 seen at CALGARY, Alta.. Nov. 10, and at OKOTOKS, Alta., 2 weeks later. Salt and Wilk (1958).

1 at SAUK RAPIDS, Minn., Nov. 20-Dec. 26. The Flicker, June, 1959 (eited by R. Huber). 1 fed on Russian Olive berries along the Missouri. River near BISMARCK, N.D., Dec. 30. Pers. corr. R. Ni. Randall. I seen at FRONTENAC, Minn.. May 11. The Flicker, Sept.. 1957. (cited by R. Huber). 2 seen by Mrs. Robin Boyd, May 17, at TWO DOT. Mont. Pers. corr. Mrs. Robin Boyd. Others (no .?) seen at LACREEK REFUGE, S.D., May 19.

1 seen twice near SIOUX FALLS. S.D., May 26.

1 seen at SASKATOON, Sask., May 31, by R. V. Folker.

Pers. corr. R. V. Folker.

1 seen at DILKE, Sask., June 2, by Boswell Beicher and Margaret Belcher. (Beicher, 1957).

1 seen at the farm of Mrs. Keyte near POLLOCKVILLE, Alta.. June 3, remained 3 days,

Pers. corr. Mrs. Mary H. Keyte. 1 found dead Sept. 11, at OXBOW, Sask., by Mrs. Keith Paton (died violently - ? howk). 1 at FORT QU'APPELLE at feeder in October, by Dr. J. G. Fyfe.

Pers, corr. Mrs, K. Paton.

Fide Manley Callin (pers. corr.). 1 heard in R.EGINI, Sask., by Fred Bard. Director S.M.N.H.

(Belcher, 196i). 1 in ST. PAUL, Minn., in Jan, and March 6-Apr. 19.

The Flicker, March, 1958. (cited by R. Huber). 1 seen in REGINA, Sask. May 14, by Elmer. Fox and F. Brazier. (Beilcher, 1961). 1 at farm of Mrs. Keyte near POLLOCKVILLE, Alta., May 31, remained 2 days, singing. Pers. corr. Mrs. Mary H. Keyte. 1 seen in S.ASKATOON, Sask.. May 25, by Dr. and Mrs. Gerrard. 1 seen in SASKATOON, Sask., by Lillian Headley. The Blue Jay, 17:17. 1 seen on a farm $6 \mathrm{mi}$. west of MOOSE JAW, Sask, July 16, by Dr. C. F. Ledingham. Belcher (1958:103).

1 taken freshly killed from the grille of a car in GLACIER NATIONIAL PARK, Mont., summer, now in collection of Montana State Univ. at Missoula, Mont.

Pers. carr. Praf. C. V. Davis.

1 seen in SASKATOON, Sask., by Lillidn Headley (same place as July sighting) in Nov.,

Audubon Field Nates, 17:17.

1. seen daily in PARSSHALL, N.D., by Mrs. R. Nordbye. Nov. 4-11.

Pers. corr. Mrs. R. T. Gamimell. 1 seen Dec. 19, at FOREST LAKE. Minn. The Flicker, Sept., 1959 (cited by R. Huber). at CALGARY, Alta.. seen for 5 weeks Dec.-Jan. 26. 1960. (Alberta's fir'st winter

1 in MINNEAPOLIS, Minn., last week of April.

The ilicker, Sept., 1959 (cited by R. Huber). banded in WASHINGTON COUNTY. Minn.. mid-April.

The Flicker, Sept., 1959 (citeid by R. Huber. 1 at DONNELLY, Mirn., May 1, and 1 at DULUTit, Minnn., early May.

The Flicker, Dec., 1959 (cited by R. Huber).

1 seen at MELVILLE, Sask.. May 4, by Gary Anweiler.

1 seen at MILLE LACS LAKE, Minn., May 16-17.

Pers, corr. Gary Anweiler. Lahrman (1959:97).

The Flicker, Sept., 1959 (cited by R. Huber). 1 at farm of Mrs. Keyte near POLLOCKVILLE, Alta., June 11, remained the day, singing. Pers corr. Mrs. Mary H. Keyte. 1 seen at GREYLING CREEK (near Yellowstone National Par) Gallatin County, Mont., June 7, by P. D. Skaar. Pers. corr. Prof. C. V. Davis. 1 seen GOOSEBERRY PARK, Minn., May 30. The Flicker, Sept., 1959 (cited by R. Huber). 1 seen in REGIN.A, Sask., June 16, by Elizabeth Barker. Belcher (1961).

Mrs. Paton saw 1 (possibly 2) at OXBOW, Sask., June 15, and July 13 (being harried by Barn Swallows), July 14, July 25. 
19591 in CASS COUNTY, Minn., during summer; 1 carrying food at BIWABIK, Minn., in 1959 l Jume 15 in SAND DUNES STATE FOREST The Flicker, Sept., 1959 (cited by R. Huber).

19594 nesting at PAYSON, Utah, 3 others reported ine Flicker, Sept., 1959 (cited by R. Huber). Audubon Field Notes, Vol. XIII No. 4 (". . . ordinarily this is an uncommon bird in

19594 were seen at DES LACS REFUGE, N.D. Aug. 23 (no details, possible family) Utah.")

1959 Immature banded at DULUTH, Minn., Aug. 28

Pers. corr. Mrs. R. T. Gammell.

The Flicker, Dec. 1959 (cited by R. Huber).

19591 seen by Erral Cochrane, FORT QU'APPELLE, Sask., Aug. 30.

19601 seen at FOREST LA.KE, Minn., Apr. 23.

Fide Manley Callin (pers. corr.).

19601 seen at BILLINGS, Mont., by Mrs. G. Hendricks, May 16.

Pers. corr. Mrs. G. Hendricks.

1960 Individuals seen at three localities near KENIMARE, N.D., between May 25-28, 1 banded by Mrs. R. T. Gammell.

Pers. corr. Mrs. R. T. Gammell.

1960 A singer stayed at ROCKYFORD, Alta., May 29-June 1, seen by Mrs. F. E. Kenworthy.

M. H. Keyte, near POLLOCKVILLE, Alta.

1960 I remained several weeks (early June to early August) at MENDHAM, Sask., singing continually.

19601 remained 2 weeks from July 19, at RALSTON, Alta., singing.

1960 I remained several Pers. corr. Mrs. Olafur Johnson.

weeks at home of Mrs. G. Headley, S.ASKATOON, Sask., in October.

19601 seen at GRENFELL, Sask., Nov. 7, by Mrs. J. Hubbard.

19601 on Christmas Bird Count of DAVENPORT, lowa, unusual.

19601 on Christmas Bird Counit of LAMONI, Iowa, unusual.

1961 I seen at CENTERVILLE, Minn., Apr. 27, by R. Grant.

1 seen at HURON, S.D., Apr. 30, was unusually early in the season.

A singer noted by Mrs. John Watson, RYEGATE, Molnt., in spring.

Fide J. Frank Roy (pers. corr.)

Audubon Field Notes, 15:224.

1961

1961

1961

1961

1961

1962

1962

1962

1962

1962

1962

1962

1962

1963

1963

1963

1963

1963

963

\section{Pers. corr. fide Mrs. Carol L. Boyd.} seen (and singing heard) May 25, 4 mi. south of WHITE SULPHUR SPRINGIS, Mont., by Lloyd Casagrada and Eldon Smith.

1 seen near GRASSRANGE, Mont., June 22, by Dr. S. E. Eng.

A by Mrs. R. Nordbye.

1 seen at REGINA, Sask., Sept. 26, by Margaret Belcher, and 1 seen there again, and taken, by $\mathrm{Dr}$. R. 'Nero, Ost' 9 , the latte' being an immature male in extreme stages of moult.

Margaret Belcher (personal files).

1 seen Nov. 21 and Nov. 29 by Tommy. Mack at LUMSDEN, Sask., feeding on honeysuckle berries. Fide Mrs. E. Cruickshank (verbal report).

1 seen in REGINA, Sask., by Elmer Fox, May $12 . \quad$ Blue Jay 20:115.

1 seen by Carol Boyd at TWO DOT, Mont., May 13. Pers. corr. Mrs. Caral Boyd.

1 seen at FORT QU'APPELLE Sask., by Maniey Callin, May 18. Callin (1962).

1 seen May 25 and off and on for two weeks by Earl J. Williams at PENINIANT, Sask.

Pers. corr. E. J. Williams. 1 identified by Doug Gilray from colour transparency of bird token at bird bath in June
at Lumsden, Sask.

1 seen Oct. 5 to Dec. 29 at PRINCE ALBERT, Sask., by Auguste Viala. Viala (1963:14).

1 seen at Legis. Grounds, REGINA, Sask., Dec. 3, by Tom Shoyama.

1 at OAK LAKE, Man., Dec. 26, by David Hatch.

T. Shayama (verbal repart).

PRINCE ALBERT, Sask., bird found dead Jan 2 (? killed by cold).

1 seen at REGINA, Sask., May 12, by Ruth Tempel and others.

Pers. corr. Auguste Viala.

Ruth Tempel (verbal report).

1 seen at SASKATOON, Sask., May 18, by J. D. Hogs and J. Shadick. Blue Jay (21:100).

1 seen at C.R.ESTWYND, Sask., June 15, by Fred Bard and F. Lahrman. SMNH record.

1 seen at ELBOW, Sask., June 26, by G. K. Greene; remained a few days singing.

1 seen at LAC DU BONNET, Man., by Bill Adams and J. J. MCDanald, Greene (1964:6). "Chickadee Notes" No. 444, Winnipeg Free Press.

1 singing at LANIGAN, Sask., July 13, 14, 15; reported to Dr. Stuart Houston by Bab Brenner, Don Eichorst and others.

1 seen at ST. LOUIS, Sask., by Auguste Viala, Aug. 10.

Pers. corr. Mrs. S. Houston.

Pers. corr. Auguste Viala.

1 seen at ST. ADOLPHE, Man., Nov, 15, by Herb Copland and Harold Hosford, in company with Bohemian Waxwings feeding on fruit of apple tree; seen again Nov. 17 by L. B. Smith. 


\section{LOCATION DIRECTORY}

\section{LOCALITY AND YEAR}

\section{Alberta}

Beynon: 1939, 1959; Calgary: 1956, 1958 19.59: Didsbury: 1928; Huxley: ?; Ókotoks: 1956; Pollockville: 1956, 1957, 1958, 1959, 1960; Rockyford: 1960 .

\section{Colorado}

Colorado Springs: 1955; Denver: 1955; Loveland: 1955; Platteville 1955.

\section{Idaho}

Driggs: 1956; Marsing1.

\section{lowa}

Davenport2; Des Maines: 1955-56; lowa City: 1955-6; Lamoniz; Waterloo: 1955-6.

\section{Manitoba}

Delta: 1939, 1946; Hillside Beachi3; Lac du Bonnet: 1963; Oak Lake: 1962; St. Adólphe: 1963; Winnipeg: 1928, 1930, 1931, 1951.

\section{Minnesota}

Aitkin County: 1952; Biwabik: 1959; Cass County: 1959; Centerville: 1961; Collegeville: 1953-4; Deer River: 1950; Donnelly: 1959; Duluth: 1959 (2 items); Ely: 1932-3; Emmons 1953; Faribault: 1949; Fertile: 1956; Forest Lake: 1958, 1960; Frontenac: 1917, 1957; Gooseberry Park: 1959; Hennepin County: 1955; Hutchinson: 1923; Madison: 1951; Mille Lacs Lake. 1959. Minneapolis: 1896,1928 1938-39, 1953, 1956, 1959; Moorhead: 1942, 1746; Parkers' Prairie: 1883; Sand Dunes State Forest: 1959; Polk County: 1951; Ramsay County: 1955; St. Paul: 1952-3, 1958; Sauk Rapids: 1956; Savage: 1953; Shroeder: 1956; Two Harbors: 1955; Waconia: 1898; Washington County: 1959.

\section{Montano}

Billings: 1943, 1953, 1954, 1955, 1960; Fort Keogh: 1935: Glacier National Park: 1958. Grassrange: 1961; Greyling Creek: 1959; Harlowton: 1957; Ryegate: 1961; Two Dot: 1962; White Sulphur Springs: 1961; Yellowstone National Park: 1959.

\section{Nebraska \\ Beatrice4; Hastings: 1955.}

\section{North' Dakota}

Bismarsk: 1952, 1956; Des Lacs Refuge: 1952, 1955, 1959; Fargo: 1953; Grand Forks: 1916; Kenmare: 1952, 1956, 1960; Minot: 1948; Mandan: 1952; Parshall: 1958, 1961; Rock Lake: 1943; Wilton: 1943.

Blitzen5.

\section{Oregon}

\section{Saskatchewan}

Beadle: 1953; Craven: 1923 or 1924; Crestwynd: 1963; Dilke: 1957; Dollard: 1935, 1946; Eastend: 1928, 1935; Elbow: 1963; Fort Qu'Appelle: 1957, 1959, 1962; Grenfell: 1960; Lanigan: 1963; Lebret: 1923 or 1924; Lumsden: 1961, 1962; Melville: 1959; Mendham: 1960; Moose Jaw: 1958; Oxbow: 1928, 1929, 1957, 1959: Pennant: 1962: Prince Albert: 1962, 1963; Regina: 1934, 1935, 1942, 1956, 1957, 1958, 1959, 1959, 1961, 1961, 1962, 1962, 1963: Renown: 1923 or 1924; Rouleau: 1935; Saskatoon: 1934, 1957, 1958, 1958, 1760, 1963; St. Louis: 1963; Skull Creek: 1927 1929; Struan: 1956; Truax: 1935; Wilcox: 1934 .

\section{South Dakota}

Ardmore: 1935-42, 1945-486; Belle Fourche 1950-2; Blact Hills: 1860; Fairburn: 19456 Highmore: 1960, 19616; Hot Springs: 1943 496; Huron: 19616; LaCreek: 1957; Millbank 1956; Marristown: 1950; Palisades Park 1956; Pierre: 1933, 19366; Platte: 1957, 1955 Sand Lake: 1956; Sioux Falls: 1957; Smith wick: 1936, 19496; Yankton: 1947.

Utah

Wisconsin

Alma: 1927.

\section{Wyoming}

Cheyenne7; Rowlins: 1956.

FOOTNOTES: Certain entries in this Location Directory have no corresponding entry Table 2, in most cases because the record a general one without specific or avaiab information about date. For these entries, th footnotes indicate the source of records.

1Marsing, Idaho: A.O.U. Check-list (1957) re Mimus polyglottos leucopterus.

2Lamoni, lowa and Davenport, lowa: Audubo Field Notes re: 1960 Christmas Bird Count 3Hillside Beach, Manitoba: A.O.U. Check-lis (1957) re: Mimus polyglottos polyglottos.

4Beatrice, Nebraska: Audubon Field Note Vol. 14, No. 3, June 1960.

5Blitzen, Oregon: Bent (1948).

GArdmore, Fairburn, Highmore, Hot Spring Huron, Pierre, Smithwick, all South Dakot South Dakota Bird Notes, 1:43.

7Cheyenne, Wyoming: Audubon Field Note Vol. 10, No. 4, August 1956.

\section{ACKNOWLEDGMENTS}

There are so many people I have thank that it is difficult to kno where to begin. Certainly, any mer this paper may have derives from th contributors whose names are show in Table 2, I wish publicly to than each and every one, particularly Ro Huber of Minneapolis who extracte the reccrds of The Flicker for $m$ as I had no useful file of this journa Mr. John Toews did the draftwor on the map-a first-class job-th obvious addenda are my own. Mi Margáret Belcher and Dr. R. W. Ner criticised and encouraged me an their spurs produced the final draf As an amateur I particularly appre ciated Dr. Nero's professional advic and assistance. 


\section{LITERATURE CITED}

American Ornithologists' Union. 1957. Checklist of North American birds. 5th ed. Baltimore.

Belcher, Boswell. 1957. Seen by a seer. Tha Blue Jay, 15:99.

Belcher, Margaret. 1958. Bird notes from a farm shelterbelt: The Blue Jay, 16:101-104.

Belcher, Margaret. 1961. Birds of Regina. Sask. Nat. Hist. Soc. Spec. Publ. \#3, Regina.

Bent, A. C. 1948. Life histories of North American nuthatches, wrens, thrashers, and their allies. U.S. Nat'I. Mus. and Smithsonian Inst., Washington.

Callin, E. M. 1962. Mockingbird at Fort Qu'Appelle. The Blue Jay, 20:111.

Findley, J. S. 1949. Mockingbirds in South Dakota. S.D. bird notes, 1(3):43.

Godfrey, W. Earl. 1950. Birds of the Cypress Hills and Flotten Lake Regions, Saskatchewan. King's Printer, Ottawa.

Greene, G. K., 1964. Mockingbird at Elbow. The Blue Jay, 22:6.

Hatch, David, ed. 1963. First Manitoba Christmas Count, 1962. The Blue Jay, 21:24-26.

Lahrman, Fred W. 1959. A report on spring migration in the Regina area. The Blue Jay, 17:96-98.

Potter, Laurence B. 1943a. Saskatchewan bird records made since the publication of
Mitchell's Catalogue of Saskatchewan birds in 192.4. The Blue Jay, 1(3):25.

Potter, Laurence B. 1943b. Bird notes from south-western Saskatchewan. Can. FieldNaturalist, 57:69-72.

Ridgway, Robert. 1907. The birds of North and Middle America, Part IV. Govt. Printing Office, Washington.

Roberts, T. S. 1936. The birds of Minnesota, Minneapolis, University of Minnesota Press.

Roy, Frank. 1958. Mockingbirds at Saskatoon. The Blue Jay, 16:108.

Sơlt, W. Ray, and A. L. Wilk. 1958. Birds of Alberta. Queen's Printer, Edmonton.

Stevens, O. A. 1948. New and unusual North Dakota trapping records. Auk, 65:136-7.

Viala, Auguste. 1963. Mockingbird at P.A. The Blue Jay, 21:14.

Wing, Leonard C. 1956. Natural history of birds. New York, The Ronald Press.

Wood, Norman A. 1923. Bird life of North Dakota. Univ. of Michigan Misc. Publ. 10:1-96.

Note: In the tables and the text of the paper there are further references to short notes without authors' names from the following journals-Audubon Field Notes, Audubon Magazine, The Auk, The Condor, The Flicker, South Dakota Bird Notes. Also, I have referred to Hugh Boyd's "About Birds", column in the Leader-Post, 1933-1937.

\section{Killdeer Photos}

\section{by Robert R. Taylor, Regina}

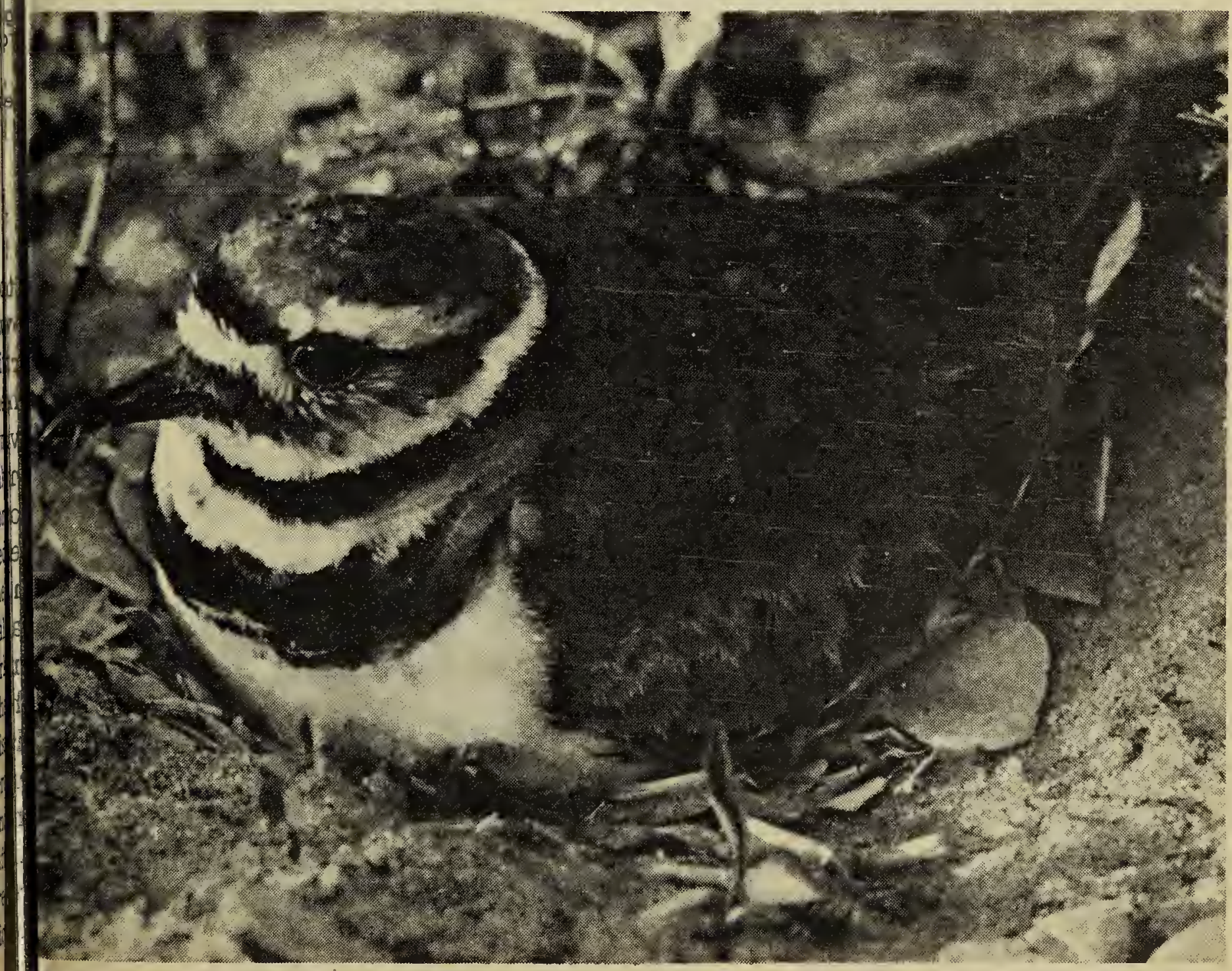

